\title{
FOOD AND FEEDING HABITS OF THE EGYPTIAN SOLE SOLEA AEGYPTIACA (CHABANAUAD, 1972), FROM PORT SAID, MEDITERRANEAN SEA, EGYPT
}

\author{
Mariam M. Sharaf ' ${ }^{1}$ Ashraf I. Ahmed ${ }^{2}$ and \\ Hebatullah A. Laban ${ }^{1}$
}

Departments of Zoology ${ }^{1}$ and of Marine Science ${ }^{2}$, Faculty of Science, Suez Canal University, Ismailia, Egypt.

Keywords: Solea aegyptiaca, stomach contents, feeding, Port Said Mediterranean Sea.

\section{ABSTABCT}

The food and feeding habits of the Egyptian Sole, Solea aegyptiaca 1 (Chabanauad, 1972) were studied in Port Said area, Mediterranean Sea during the period from October 2004 to September 2005. The annual composition of the diet, the intensity of feeding, seasonal variation of diet composition and variation of diet with length, showed a low-intensity of feeding activity of $S$. aegyptiaca, and indicated that they feed on a wide variety of prey types (polychaetes, mollusks, amphipods, sediments and small quantities of crustacean fragments, Ascidia, fish parts, sea grasses, brittlestars, unknown medusae and algae), with a limited variation in diet among seasons. The prey types and size differed from juvenile to adults, juvenile ingested only 5 small prey items; while adult had eaten about 11 of large sized prey items. The diet composition of Egyptian sole is indicative of a generalist feeding strategy.

\section{INTRODUCTION}

Flatfishes (Pleuronectiformes) are a successful group of marine temperate shallow water fishes with approximately 520 extant species (Nelson, 1976). They are considered one of the most important predators in benthic communities.

Many studies on the feeding habits of flatfishes that have been conducted all over the world, included these; in the Bering Sea, Gulf of Alaska (Livingston, 1993; 1995), showed that flatfish primarily consume benthic invertebrates, with some larger, wider-gaped species being almost 
entirely piscivorous. Other studies from the Mediterranean Sea (De Morais and Bodiou, 1984), New Zealand waters (Livingston, 1987), the Baltic Sea (Aarnio et al., 1996), the Pacific, Kamchatkan Peninsula (Orlov, 1997), the North Sea (Kaiser and Ramsay, 1997) and the Canadian/American Atlantic waters (Methven, 1999) are consistent with this global pattern. Flatfish serve as a major energy pathway for conservation of benthic production into a form suitable for human consumption.

De Groot (1971) found that flatfish tend to be of different feeding groups; fish-feeders, crustacean-feeders, polychaete/mollusks-feeders, thereby minimizing competition for food (Lande 1973; Stickney et al., 1974; Kravitz et al., 1977; Pearcy and Hancock 1978; Steinarsson, 1979).

Soleids (Solea solea and Solea senegalensis), have been considered apt for commercial aquaculture since the end of the $19^{\text {th }}$ and the beginning of the $20^{\text {th }}$ century (Person-Le-Ruyet, 1986). Although there are still some constraints to full development, it remains a very interesting candidate to diversify the offer of cultured species (Howell, 1997; Flos et al., 1998; Dinis et al., 1999).

Since the position of the Egyptian sole, Solea aegyptiaca, in the trophic structure of the eastern Mediterranean Sea, Port Said area, is poorly understood, so, the present work aimed to define the trophic relationships between Egyptian sole with other invertebrates and fishes in this area, as an important step in understanding the dynamics of this regional ecosystem. Beside, results from feeding habits of $S$. aegyptiaca may have direct implications for its local aquaculture.

\section{MATERIALS AND METHODS}

The stomach contents of 592 flatfish individuals were examined, on a monthly basis, from October 2004 to September 2005, from the commercial catch (trawl nets) from different fishing sites in Port Said. For each specimen, length to nearest $(0.1 \mathrm{~cm}$.) was recorded.

The stomachs were removed and individually stored in $10 \% \mathrm{NaCl}$ formalin solution. For each fish, the stomach was opened and its contents were removed in $0.9 \% \mathrm{NaCl}$. The prey items were separated into the main taxonomic groups, then, a list of general diet composition was made and the numbers of different food items were counted and expressed as a percentage of total.

In the present study, the occurrence method was adopted and the visual estimation for the volume of each food item was made in order to 
apply a point method (Hynes, 1950), then, the results were subjected to further statistical analysis according to Godfriaux (1969), in order to give more precise information about food and feeding habits of $S$. aegyptiaca.

Length at the first maturation was calculated to differentiate between juveniles and adults of the target species.

\section{RESULTS}

The total length of the examined $S$. aegyptiaca ranged from $9.5 \mathrm{~cm}$. to $31.5 \mathrm{~cm}$ with a mean value of $18.9 \mathrm{~cm}$.

\section{Annual composition of diet}

In $S$. aegyptiaca, the diet composition was represented graphically in Figure (1). Polychaetes made up the major bulk of the diet $(41.18 \%)$ by the volume composition of the whole population. The next major food items were supplemented by mollusks which included bivalves and gastropods, (12.65\%), amphipods (11.26\%) and sediments $(10.38 \%)$. The minor focd items included crustacean fragments $(7.95 \%)$, Ascidia $(4.59 \%)$, fish parts comprising fish scales, bones, fins rays and spines, $(4.77 \%)$, sea grasses $(3.88 \%)$, brittlestars $(2.88 \%)$, unknown medusae $(0.6 \%)$ and algae $(0.4 \%)$.

\section{Seasonal variation in feeding intensity}

The results of feeding intensity are illustrated in Table (1). $S$. aegyptiaca showed a low rate of feeding activity. Fishes whose stomachs were half full, almost full and full of food amounted to $6.7 \%$, while fishes whose stomachs were empty or have traces of food were represented by $93.3 \%$ of the total specimens.

The feeding intensity revealed seasonal variation, since it was high during autumn (11.4\%), followed by winter (6.7\%) and spring (6.1\%), while the lowest value was recorded during summer $(2.7 \%)$.

\section{Monthly variation in diet composition}

Monthly variation in diet composition of $S$. aegyptiaca is represented in Table (2) and Figure (2). Polychaetes occurred in all months except July, ranging from $87.0 \%$ in October to $18.1 \%$ in January, and dominated the whole items in September $(78.7 \%)$, October $(87.0 \%)$, November $(83.9 \%)$ and December $(76.3 \%$ by volume composition).

Mollusks occurred in the period from January to June, ranging from $51.6 \%$ in March to $2.3 \%$ in June, dominating the whole items in February (41.0\%), March (51.6\%) and May (31.4.\%). Amphipods and 
sediments ranged from $38.1 \%$ and $47.6 \%$ respectively in July, to $1.1 \%$ for both items in December by volume composition.

Crustacean fragments occurred in all months except in July and August, ranging from $20.3 \%$ in January to $1.9 \%$ by volume composition in September. Ascidia dominated the whole food items in January (46.1 $\%$ ), though it occurred from October to February, attaining the lowest value in October $(0.6 \%$ by volume composition). Fish parts were the major food items in August (42.0\%), whereas the lowest value was recorded in December and September (1.3\% by volume composition). Sea grasses occurred in all months except in January, March and April, ranging from $14.4 \%$ in June to $1.0 \%$ by volume composition in October. Brittle stars recorded in June $8.4 \%$ and in August $19.6 \%$ by volume composition. Some medusae occurred in May (3.9\%) and in June (3.3 $\%)$, while Algae occurred in May, August (2.0\%) and October $(0.8 \%$ by volume composition).

\section{Food habits in relation to fish size}

The variation of food items with length was illustrated in Table (3) and presented graphically in Figs. ( $3 a$ and $b$ ). Within the length group study of the Egyptian Sole population, twenty-five classes ranging from 9.5 to $32.4 \mathrm{~cm}$ with $1.0 \mathrm{~cm}$ interval were obtained. Prey size differed between juveniles and adults; adults had ingested the large-size prey, whercas the juveniles ingested the small-size prey.

Juveniles of $S$. aegyptiaca (Fig. 3A) were classified into six classes from 9.5 to $15.4 \mathrm{~cm}$, they consumed oniy 5 types of food items, where polychaetes were the most dominant, constituting $35.0 \%$ by volume composition in all juvenile diet. Polychaetes supplemented by amphipods which constituted $8.3 \%$ by volume composition. They occurred in size range from 13.5 to $15.4 \mathrm{~cm}$ long, varying from $59.0 \%$ and $16.2 \%$ respectively in size class $13.5-14.4$ to $77.7 \%$ and $23.3 \%$ respectively in size class 14.5-15.4.

Crustacean fragments were the second most important food item representing $23.8 \%$, followed by sediments (20.8\%) and mollusks (12.1 $\%$ ) in all juveniles diet that occurred in size range from 10.5 to $14.4 \mathrm{~cm}$. long.

Adults (Fig. 3B) were classified into nineteen classes from 13.5 to $32.4 \mathrm{~cm}$; where polychaetes and amphipods occurred in size range from 14.5 to $24.4 \mathrm{~cm}$. long, varying from $6.1 \%$ in size class $22.5-23.4$ to $64.2 \%$ in size class $16.5-17.4$, and $4.2 \%$ in size class $16.5-17.4$ to $34.3 \%$ in size class $14.5-15.4$ respectively by volume composition. 
Crustacean fragments and sediments were ingested by size range from 14.5 to $26.4 \mathrm{~cm}$. long, varying from $1.6 \%$ in size class $15.5-16.4$ to $80.0 \%$ in size class $25.5-26.4$, and $2.0 \%$ in size class $15.5-16.4$ to $31.8 \%$ in size class $22.5-23.4$ respectively by volume composition.

Mollusks were ingested by size range from 14.5 to $22.4 \mathrm{~cm}$ long, varying from $9.1 \%$ in size class $14.5-15.4$ to $56.6 \%$ in size class $21.5-$ 22.4 by volume composition. Ascidia occurred in size range from 14.5 to $23.4 \mathrm{~cm}$ long, varying from $1.3 \%$ in size class $19.5-20.4$ to $13.9 \%$ in size class $16.5-17.4$ by volume composition.

Fish parts and sea grasses occurred in size range from 14.5 to 25.4 $\mathrm{cm}$. long, varying from $33.3 \%$ and $30.0 \%$ respectively in size class 24.5 25.4 to $0.8 \%$ in size class $20.5-21.4$ and $1.5 \%$ in size class $18.5-19.4$ respectively by volume composition.

Brittle stars, medusae and algae were occasionally taken; brittle stars were ingested by size class $20.5-21.4 \mathrm{~cm}$. and $24.5-25.4 \mathrm{~cm}$. by 4.4 $\%$ and $20.0 \%$ respectively. Medusae occurred in size range from 20.5 to $22.4 \mathrm{~cm}$. long, varying from $1.9 \%$ to $6.3 \%$. Algae occurred in size classes $14.5-15.4 \mathrm{~cm}, 18.5-19.4 \mathrm{~cm}$. and $25.5-26.4 \mathrm{~cm}$ by $1.6 \%, 1.3 \%$ and $16.0 \%$ respectively by volume composition.

\section{DISCUSSION}

Diets of fishes are related not only to their feeding behavior but also to their digestive morphology and mouth structure (Stickney et al., 1974). Generally flatfishes which are polychaetes-feeders have asymmetrical jaws (Stickney, 1976; De Morais aná Bodiou, 1984; Collie, 1987; Rajaguru, 1992; Aarnio et al., 1996; Methven, '1999); and characterized by their small stomach (not highly demarcated), long intestine and lack of gill rakers and pyloric ceaca (Rajaguru, 1992).

In the present work, Solea aegyptiaca feeds predominantly on polychaetes $(41.18 \%)$ supplemented by mollusks $(12.65 \%)$ and amphipods ( $11.26 \%$ by volume composition), whereas sediments, crustacean fragments, fish parts and Ascidia were minor food items for the target species. This in agreement with S. solea (Quiniou, 1978; Ramos 1981; Lagardere, 1987; Molinero et al., 1991; Cabral, 2000), S. vulgaris (Ramos, 1981; Lagardère, 1987; Henderson et al., 1992), S. senegalensis (Cabral, 2000) and Buglossidium luteum (Amara et al., 2004). However, Sá et al. (2003) reported that the food items consumed by $S$. vulgaris in the Guadiana estuary (Portugal), consists of a low variety of prey (only polychaetes and Tanaidacea). 
In the current work, some individuals were observed with full and gorged stomachs with polychaetes or polychaetes supplemented by amphipods. This might indicate either greater availability or patchy distribution of the major food items. Seshappa and Bhimachar (1955) and Rajaguru (1992) reported the same observation on Malabar sole and the tongue fishes in Indian water.

In the present work, sediments constitute about $10.38 \%$ by volume composition of the main bulk of $S$. asgyptiaca. This abundance was recorded in other flatfishes, such as Malabar sole (Seshappa and Bhimachar, 1955), and tongue fishes (Rajaguru, 1992). Stickney (1976) stated that the high percentage occurrence of sand in the stomachs of black cheek tonguefish Symphurus plagiusa might be due to ingestion of a significant quantity of deterial material in its feeding activity. Rajaguru. (1992) recorded that the sediments were probably ingested accidentally' with bottom living polychaetes and other fauna.

In the current work, although the primary diets of this demersal flatfish consisted of benthic prey, such as polychaetes, mollusks, it was surprising to find pelagic amphipods; $1.26 \%$ by volume composition and other crustaceans; $7.95 \%$ by volume composition with also relative importance in their diets. especially in juvenile. Egyptian Sole is a demersal flatfish that has never been caught in the pelagic water, either during day or night, and is not known to undergo vertical feeding migration. Pereyra et al. (1969) have reported that in eastern North Pacific Ocean, demersal fishes feed on pelagic prey, when such prey approach the bottom along the edge of the continental shelf.

Although there were similarities in food items, the importance of prey species differed from juvenile and adults. In the current work. Juveniles of $S$. aegyptiaca probably owing to their very small mouths, fed predominantly on smaller prey, as crusiaceans and young polychaetes, and ingested fewer types (only 5) of food items. Adults of S. aegyptiaca, in contrast, had eaten 11 types of relative large-sized prey, primarily large polychaetes, mollusks, crustacean fragments and fish remains; This in agreement with Stickney (1976) who concluded that the mouth size severely limits the size of the ingested prey. Rajaguru (1992) studied the difference in food items chosen between juveniles and adults in other species of flatfishes and recorded that tongue fishes are benthophagus; where the adults feed primarily on polychaetes, while juveniles more often consume smaller prey such as hypriid amphipods and copepods. 
The extent of food demands and ability for food acquisition increase with growth and development of fishes (Honda, 1984). Lande (1976) study on the Dab Limanda limanda, revealed that larger fish consumed large-sized prey compared with the smaller fish. Pearcy and Hancock (1978) on Dover Sole Microstomus pacificus; Rex Sole Glyptocephalus zachirus; Slender Sole Lyopsetta exilis; and Pacific Sand Dab Citharichthys sordidu off Oregon, and Rajaguru (1992) on the tongue fishes, Cynoglossus arel, and C. lida in Indian water, concluded that the number and the size of prey generally increased with size in these flatfishes, due to the ability of larger fishes to consume a larger range of prey sizes than smaller fishes.

In the present work, the feeding intensity of S. aegyptiaca represents a low rate of feeding activity which changes seasonally, to be high during autumn, moderate during winter and spring and low during summer. The variations of diet composition with seasons revealed that in autumn; polychaetes and amphipods were the major items supplemented by crustacean fragments, sea grasses, fish parts, whereas the minor were Ascidia and algae. There was no sign of mollusks, brittlestars and unknown medusae. In winter; polychaetes were the major, followed by Ascidia, mollusks and crustacean fragments, and a small quantities of sediments, amphipods, sea grasses and fisin parts. In spring; mollusks and polychaetes were the major items supplemented by amphipods, crustacean fragments, fish parts, sea grasses, unknown medusae and algae. Ascidia and brittlestars were absent. In summer; sediments were the major food item supplemented by amphipods, polychaetes and fish parts, whereas sea grasses. brittlestars, crustacean fragments, algae and mollusks were minor.

In the present work, the low feeding intensity of S. aegyptiaca was probably due to a high rate of gastric evacuation. De Groot (1971) reported that $S$. vulgaris due to its characteristics digestive tract and a rapid digestive process, it feeds on small quantities of prey very often. This suggests a high evacuation rate between the stomach and the intestine, and lack of digestion in the stomach (Lagardère, 1987). This high evacuation values has also found for $S$. solea and S. senegalensis (Quiniou, 1978; Ramos, 1981; Molinero et al., 1991; Cabral, 2000). 


\section{ACKNOWLEDGEMENTS}

Deep gratitude and sincere appreciation to Dr. Mahmoud E. Mohallal, Professor of Histology and Histochemistry, Faculty of Science, Suez Canal University, Ismailia, Egypt, for his kind supervision, encouragement and valuable advise, as this study is a part of M. Sc. thesis.

\section{REFERENCES}

Aarnio, K.; Bonsdorff, E. and Rosenback, N. (1996). Food and feeding habits of juvenile flounder Platichthys flesus (L.) and turbot Scophthalmus maximus (L.) in the Aaland Archipelago, Northern Baltic Sea. J. Sea Res., 36: 311-320.

Amara, R.; Mahéa, K.; LePapeb, O. and Desroyc, N. (2004). Growth, feeding and distribution of the solenette Buglossidium lute um with particular reference to its habitat preference. J. Sea Res., 51(3-4): 211-217

Cabral, H. N. (2000). Comparative feeding ecology of sympatric Solea solea and $S$. senegalensis, within the nursery areas of the Tagus estuary. Portugal. J. Fish Biol. 57, 1550-1562.

Collie, J. S. (1987). Food consumption by yellowtail flounder in relation to production of its benthic prey. Mar. Ecol. Pro. Ser., 36: $205-213$.

De Groot, S. J. (1971). On the interrelationships between morphology of the alimentary tract, food and feeding behaviour in flatfishes (Pisces: Pleuronectiformes). Netherlands J. Sea Res., 5:121196.

De Morais, T. L. and Bodiou, J. Y. (1984). Predation on meiofauna by juvenile fish in a western Mediterranean flatfish nursery ground. Mar. Biol., 82: 209-215. 
Dinis, M.T.; Ribeiro, L.; Soares, F. and Sarasquete, C. (1999). A review on the cultivation potential of Solea senegalensis in Spain and Portugal. Aquacult., 176:27-38.

Flos, R; Hussenot, J. and Lagardère, F., (1998). Les soles, quelles recherches, pour quels types d'élevage et de production? Marais Maritimes et Aquacult. IFREMER Actes de Colloque, 19:155-164.

Godfriaux, B. L. (1969). Food predatory demersal fish in Hauraki Gulf. 1. Food and feeding habits of the snapper Chrysophyrs auratus. N. Z. Mar. Freshw. Res., 3, 518- 544.

Henderson, P. A.; James, D. and Holmes, R. H. A. (1992). Trophic structure within the Bristol Channel: seasonality and stability in Bridgewater Bay. J. Mar. Biol. Ass. U. K., 72: 675-690.

Honda, H. (1984). Food acquisition patterns in some demersal telosts. Tohoku J. Agric. Res. 35 (1): 33 - 54.

Howell, B.R., (1997). A re-appraisal of the potential of the sole Solea solea (L.), for commercial cultivation. Aquacult. 155: 355365 .

Hynes, H. B. (1950). The food of fresh water sticklebacks (Gasterosteus aculeatus and Pygosteus pungitius) with a review of methods used in studies of food fishes. J. Anim. Ecol., 19: $36-58$.

Kaiser, M. J. and Ramsay, K. (1997). Opportunistic feeding by daps within areas of trawl disturbance: Possible implications for increased survival. Mar. ecol. Prog. Ser., 152: 307-310. 
Kravitz, M. J.; Pearcy, W. G. and Gunn, M. P. (1977). Food of five species of co-occurring flatfishes on Oregon's continental shelf. Fish. Bull., 74: 983- 990.

Lagardère, J.P. (1987). Feeding ecology and daily food consumption of common sole, Solea vulgaris, Quensel, juveniles on the French Atlantic coast. J. Fish Biol.,30: 91-104.

Lande, R. (1973). Food and feeding habits of place (Pleuronectes platessa L.) in Borgenfjorden, north- Trondelag, Norway. Norw. J. Zool., 21: 91-100.

Lande, R. (1976). Food and feeding habits of dab (Limanda limanda \{L.\}) In Borgenfjorden, north- Trondelag, Norway. Norw. J. Zool., 24 (3): 225-230.

Livingston, M. E. (1987). Food resource use among five flatfish species (Pleuronectiformes) in Wellington Harbour, New Zealand. J. Mar. Freshwat. Res., 21: 281-293.

Livingston, P. A. (1993). Importance of predation by ground fish. marine mammals and birds on walleye Pollock Theragra chalcogramma and Pacific herring Clupea pallasi in the eastern Bering Sea. Mar. Ecol. Prog. Ser., 102: 205-215.

Methven, D. A. (1999). Annotated bibliography of demersal fish feeding with emphasis on selected studies from the Scotian Shelf and Grand Banks of the northwestern Atlantic. Can. Tech. fish. Aquat. Sci., 2267: 110pp.

Molinero, A.; Garcia, E. and Flos, R. (1991). Comparative study of the feeding habits for two species of sole: Solea vulgaris and Soiea senegalensis. Special Pub. Europ. Soc. Aquacult., 14: 219-220.

Nelson, J. S. (1976). Fishes of the world. New York: John Wiley and Sons., 416 pp. 
Orlov, A. M. (1997). Role of fishes on predator diets of the Pacific slope of the northern Kuril Islands and southeastern Kamchatka. Int. Symp. On the role of the forage fishes in marine ecosystems. Lowell Wakefield Fisheries Symposium Series, 14: 209-229.

Pearcy, W. G. and Hancock, D. (1978). Feeding habits of Dover sole, Microstomus pacificus; rex sole, Glyptocephaius zachirus; slender sole, Lyopsetta exilis; and pacific sand dab, Citharichthys sordidus; in a region of diverse sediments and bathymetry off" Oregon. Fish. Bull., 76: 641-651.

Pereyra, W. T.; Pearcy, W. G. and Carvey Jr, F. E. (1969). Sebastes flavidus, a shelf rockfish feeding on mesopelagic fauna, with consideration of the ecological implication. J. Fish. Res. Board Can.. 26: 2211 - 2215 .

Person-Le-Ruyet, J., (1986). L'élevage des poissons plats : sole, turbot. In:Barnabé, G. (Ed.), Aquaculture, vol. 2. Technique et Documentation-Lavoisier, Paris, pp. 667-712.

Quiniou, L. (1978). Les poissons demersaux de la Baie de Dournenez. Alimentation et ecologie. The' se $3 e^{\prime}$ me cycle, Universite' de Bretagne Occidentale.

Rajaguru, A. (1992). Biology of co-occurring tonguefishes, Cynoglossus arel, and C. lida (Pleuronectiformes: Cynoglossidae), from Indian waters. Fish. Bull. , U. S, 90: 328- 367.

Ramos, J. (1981). Régimeny comportarniento alimentario del lenguado (Solea solea L.) (Pises, Soleidae). Informes Técnicos del Instituto de Investigación Pesquera, 83:-3-15.

Sá,R.; Bexiga, C.; Vieira, L.; Veiga P. and Erzini K. (2003). Diets of the sole Solea vulgaris Quensel, 1806 and Solea senegalensis Kaup, 1858 in the lower estuary of the Guadiana River 
(Algarve, southern Portugal): Preliminary results. Bol. Inst. Esp. Oceanogr., 19 (1-4): 505-508.

Seshappa, G. and Bhimachar, B. S. (1955). Studies on the fishery and biology of the Malabar sole Cynoglossus semifasciatus Day. Indian J. Fish., 2 (1): 180-230.

Stickney, R. R.; Taylor, G. L and Heard, R. W. (1974). Food habits of Georgia estuarine fishes. 1. Four species of flounders (Pleuronectiformes: Bothidae). Fish. Bull., 72: 515-524.

Stickney, R. R. (1976). Food habits of Georgia estuarine fishes. II. Symphurus plagiusa (Pleuronectiformes: Cynoglossidae). Trans. Am. Fish. Soc., 105 (2): 202-207.

Steinarsson, B. (1979). The food of lemon sole (Microstomus leitt Walbaum), megrim (Lepidorhombus whiffiagonis Walbaum), and witch (Glyptocephalus cynoglossus L.) in Icelandic waters. Meeresforschungen, 27: 156-171.

Yang, M. S. (1995). Trophic role of Atka mackerel (Pleurogrammus monopterygius) in the Aleutian Islands. Int. Symp. On the role of forage fishes in marine ecosystems, Lowell Wakefield Fisheries Symposium Series, 14: 277-279. 
Table (1): Monthly variation in the intensity of feeding of Solea aegyptiaca.

\begin{tabular}{|c|c|c|c|c|c|c|c|c|c|}
\hline Month & $\begin{array}{l}\text { Fish } \\
\text { No. }\end{array}$ & Empty & Poor & $\begin{array}{l}1 / 4 \\
\text { Full }\end{array}$ & $\%$ & $\begin{array}{c}1 / 2 \\
\text { Full }\end{array}$ & $\begin{array}{c}3 / 4 \\
\text { Full }\end{array}$ & Full & $\%$ \\
\hline Oct-04 & 50 & 48.0 & 26.0 & 6.0 & 80.0 & 10.0 & 8.0 & 2.0 & 20.0 \\
\hline Nov-04 & 50 & 70.0 & 16.0 & 4.0 . & 90.0 & 4.0 & 4.0 & 2.0 & 10.0 \\
\hline Dec-04 & 48 & 72.9 & 14.6 & 8.3 & 95.8 & 2.1 & 2.1 & 0.0 & 4.2 \\
\hline Jan-05 & 49 & 63.3 & 32.7 & 2.0 & 98.0 & 0.0 & 2.0 & 0.0 & 2.0 \\
\hline Feb-05 & 50 & 46.0 & 32.0 & 8.0 & 86.0 & 10.0 & 2.0 & 2.0 & 14.0 \\
\hline $\begin{array}{c}\text { Mar- } \\
05\end{array}$ & 50 & 58.0 & 24.0 & 12.0 & 94.0 & 4.0 & 2.0 & 0.0 & 6.0 \\
\hline Apr-05 & 49 & 51.0 & 34.7 & 8.2 & 93.9 & 6.1 & 0.0 & 0.0 & 6.1 \\
\hline $\begin{array}{c}\text { May- } \\
05\end{array}$ & 50 & 72.0 & 16.0 & 2.0 & 90.0 & 0.0 & 4.0 & 2.0 & 6.0 \\
\hline Jun-05 & 50 & 62.0 & 32.0 & 2.0 & 96.0 & 2.0 & 0.0 & 2.0 & 4.0 \\
\hline Jul-05 & 49 & 85.7 & 12.2 & 2.0 & 100.0 & 0.0 & 0.0 & 0.0 & 0.0 \\
\hline Aug-05 & 49 & 75.5 & 18.4 & 2.0 & 95.9 & 4.1 & 0.0 & 0.0 & 4.1 \\
\hline Sep-05 & 48 & 79.2 & 8.3 & 8.3 & 95.8 & 4.2 & 0.0 & 0.0 & 4.2 \\
\hline Total & 592 & \multicolumn{4}{|c|}{$93.3 \%$} & \multicolumn{4}{|c|}{$6.7 \%$} \\
\hline
\end{tabular}




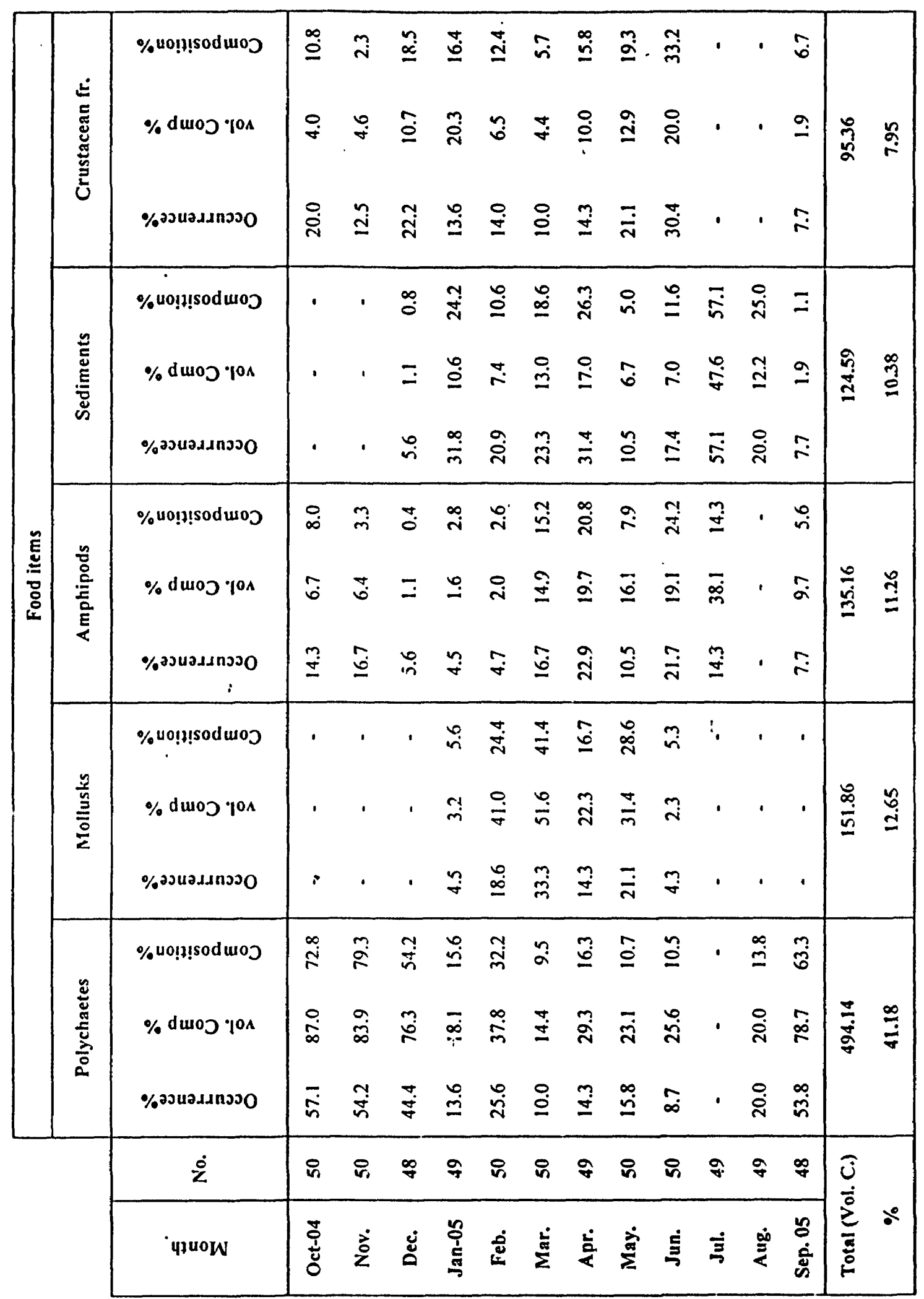




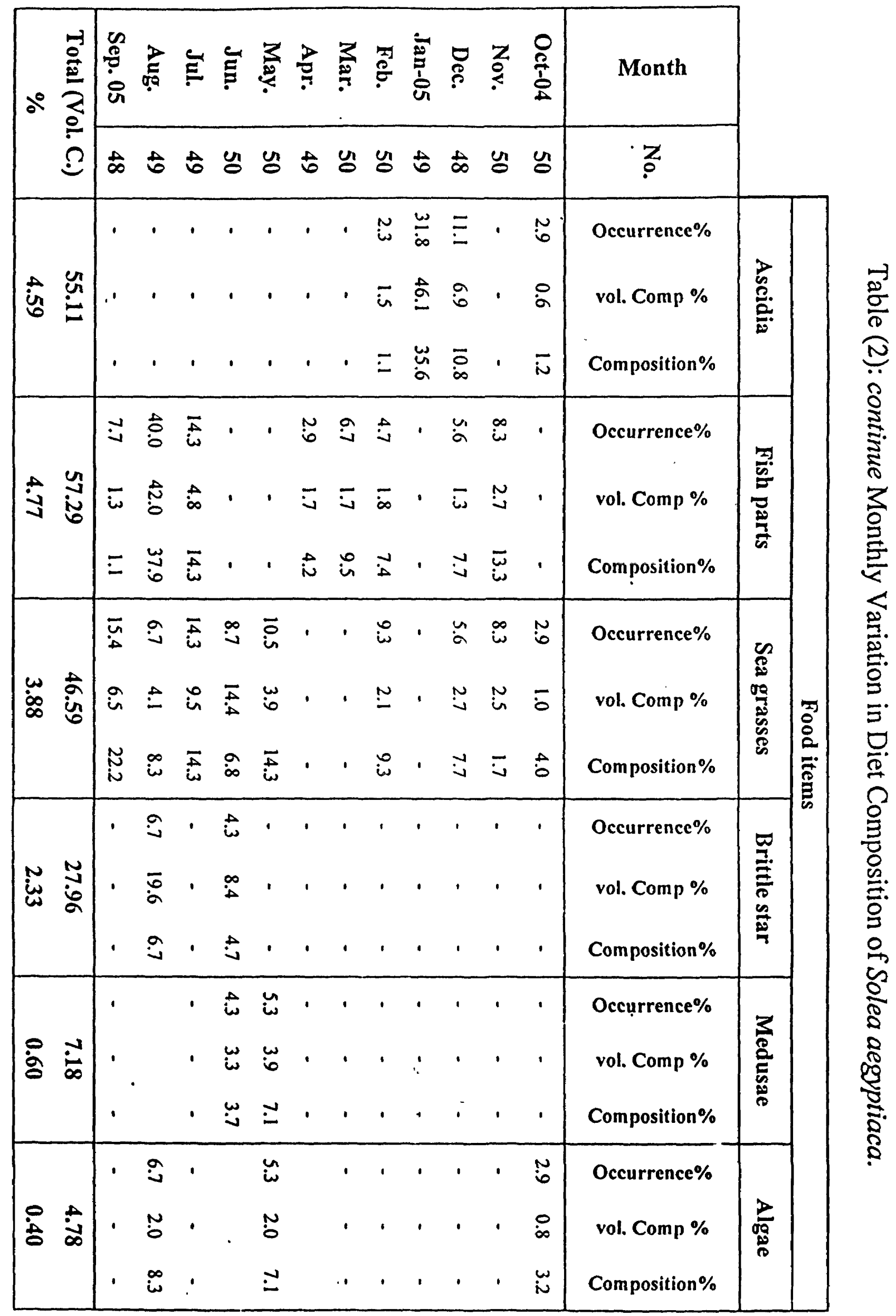




\begin{tabular}{|c|c|c|c|}
\hline 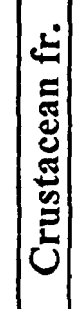 & $\%$ duroj ros & 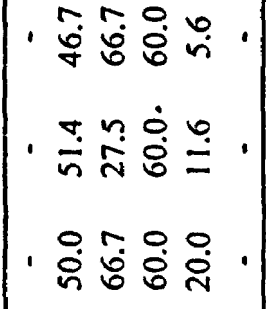 & 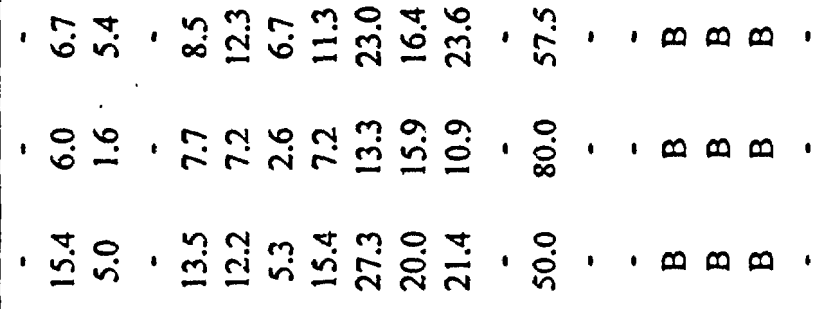 \\
\hline 常 & 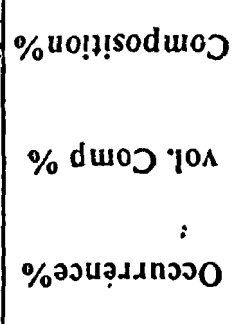 & 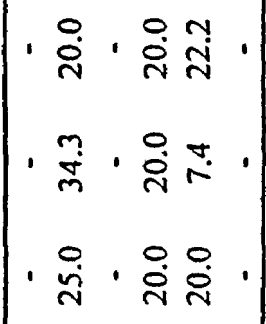 & 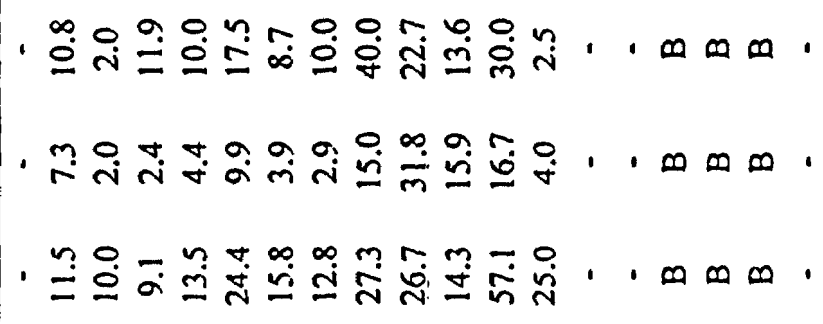 \\
\hline 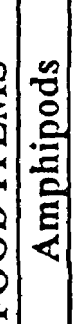 & $\left\{\begin{array}{l}\% \text { uo!n!soduro } \\
\% \text { dusoj } \% 0 x\end{array}\right.$ & 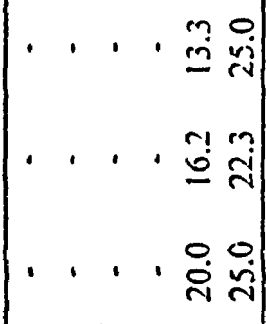 & 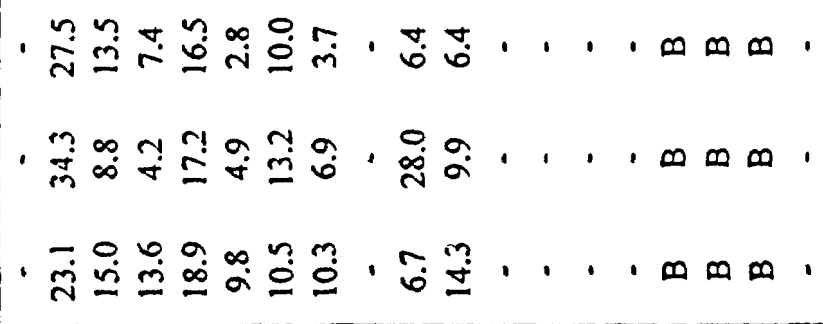 \\
\hline$\frac{2}{\frac{2}{0}}$ & 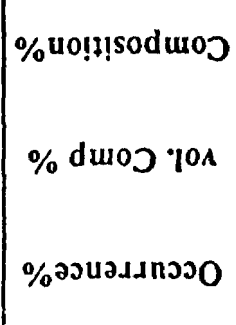 & 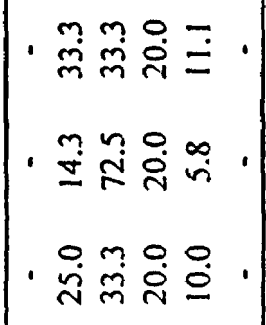 & 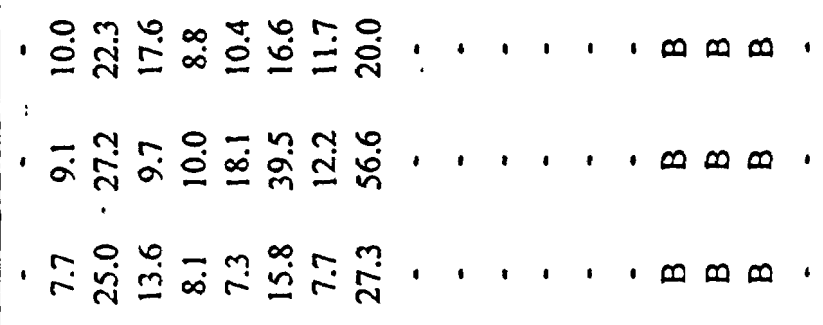 \\
\hline 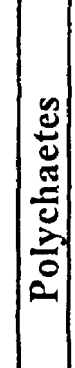 & $\%$ uo!!! soduro & 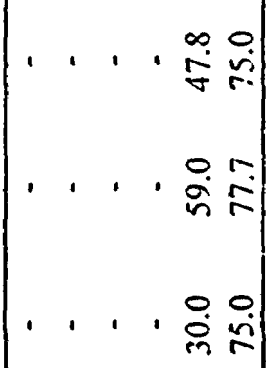 & 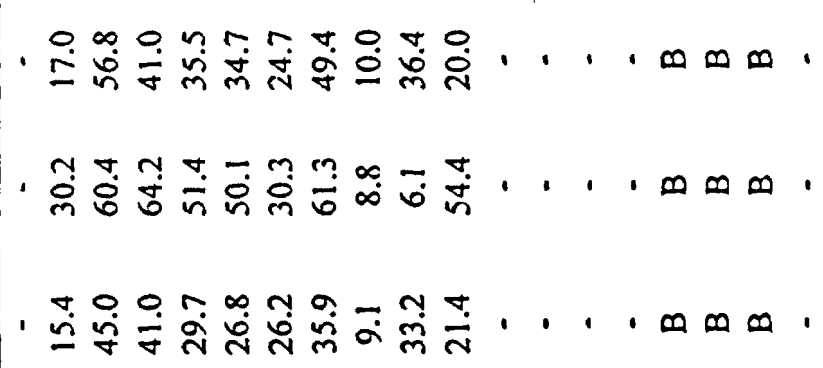 \\
\hline & $\dot{z}$ & $\nabla \sigma \geq \pm \pm 0$ & 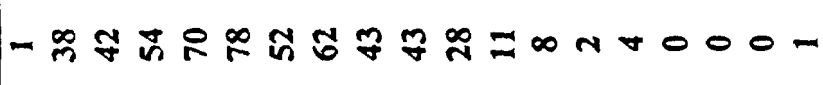 \\
\hline & 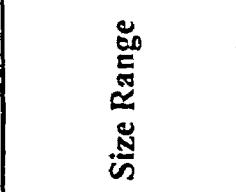 & 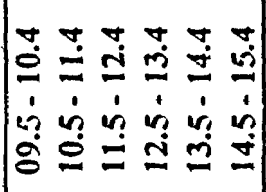 & 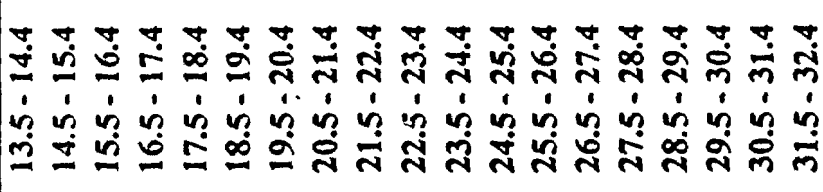 \\
\hline & & & \\
\hline
\end{tabular}




\begin{tabular}{|c|c|c|c|c|}
\hline$\stackrel{\dot{\partial}}{ٍ}$ & 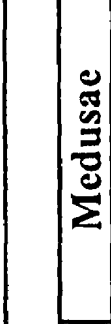 & 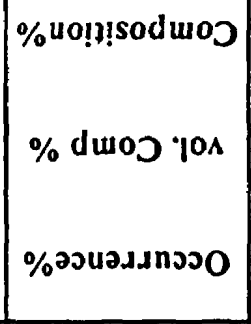 & 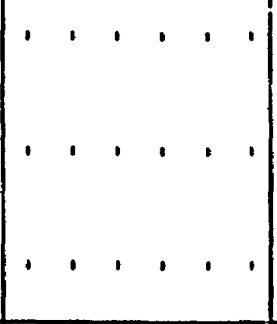 & 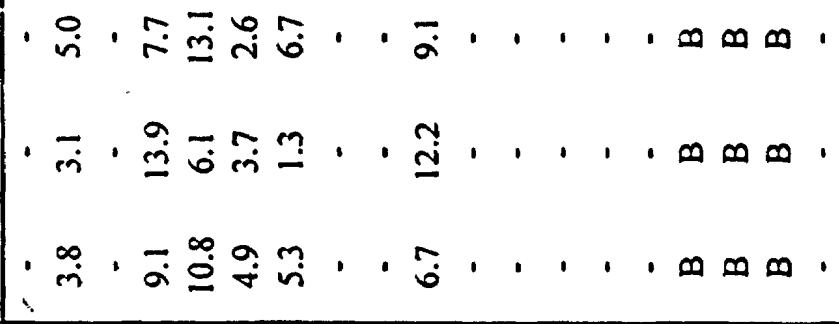 \\
\hline 0 & 吾 & 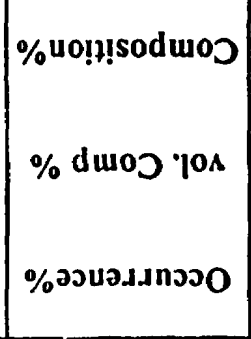 & 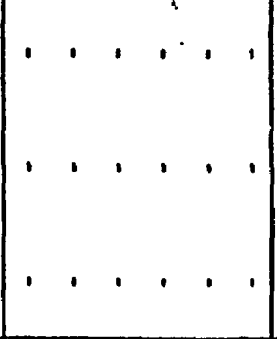 & 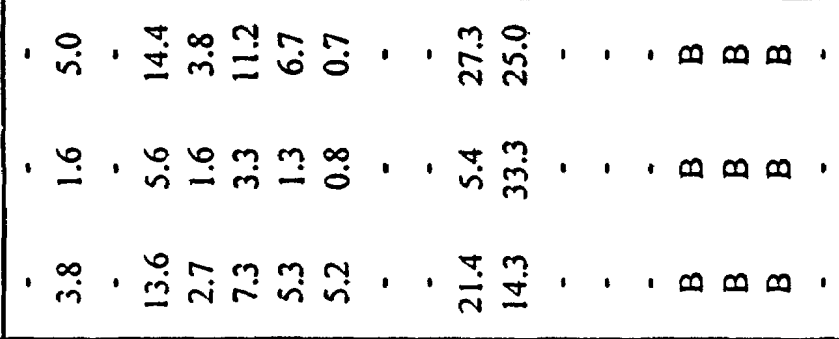 \\
\hline ర్ & 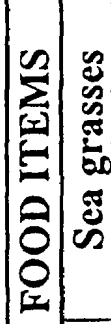 & 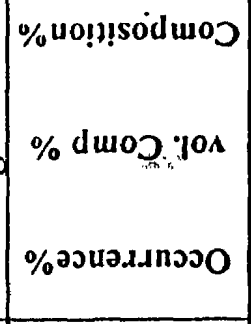 & 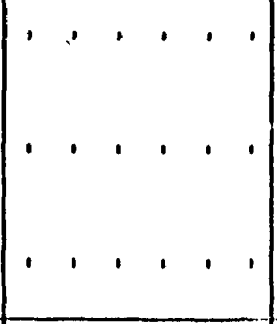 & 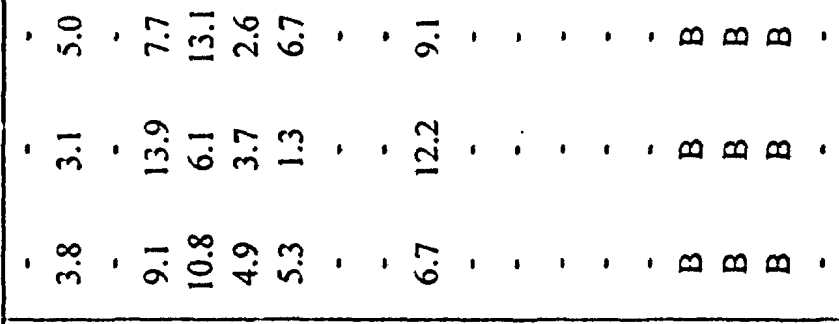 \\
\hline 艺 & 党 & 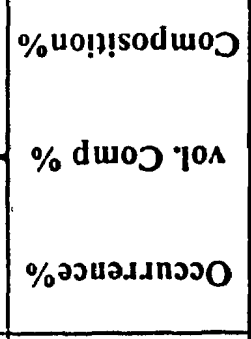 & 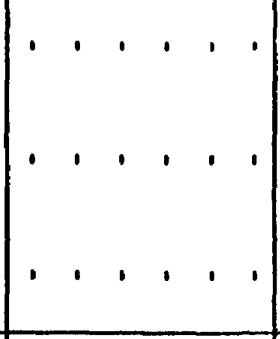 & 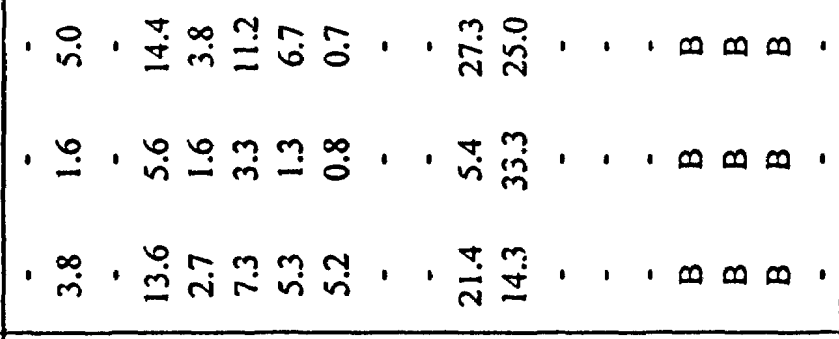 \\
\hline 요 & 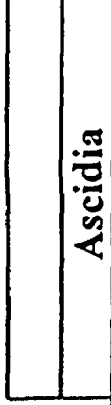 & 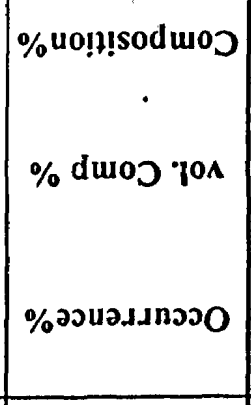 & 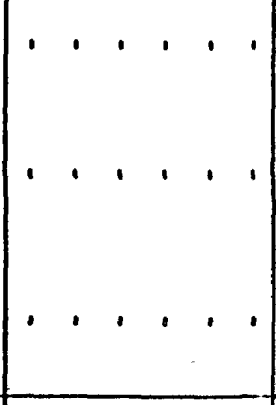 & 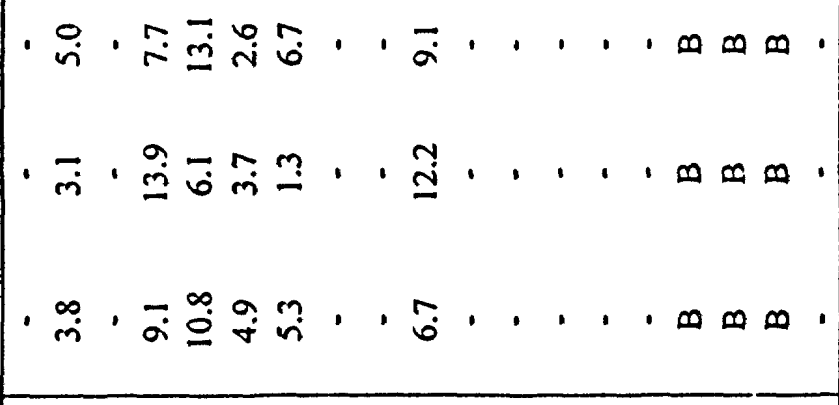 \\
\hline & & $\dot{z}$ & $\nabla \nabla \pm \pm 0$ & - \\
\hline 2 & & 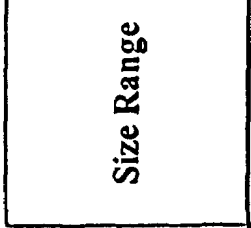 & 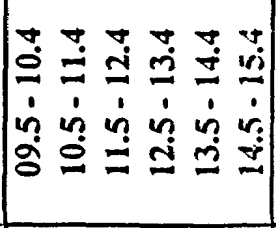 & 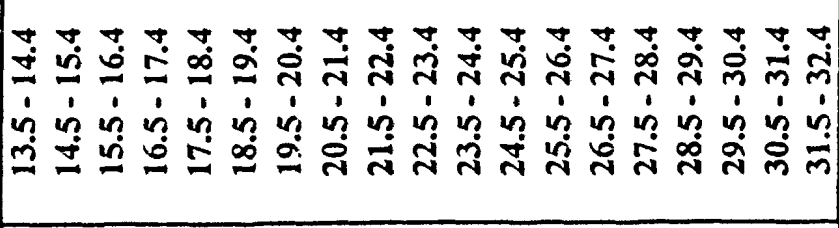 \\
\hline & & & 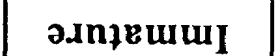 & วגn‡ew \\
\hline
\end{tabular}




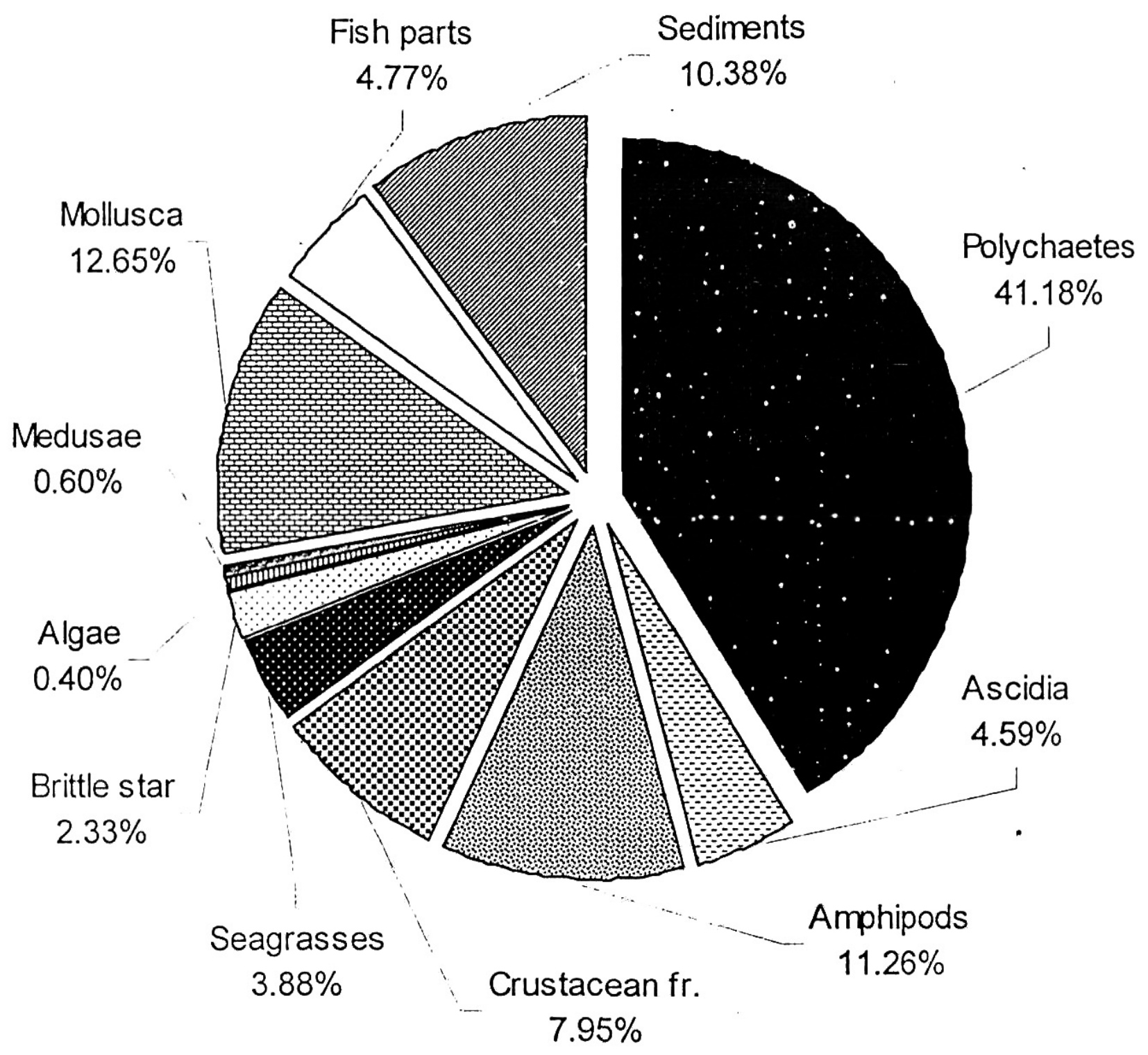

Figure (1): Diet Composition of Solea aegyptiaca. 


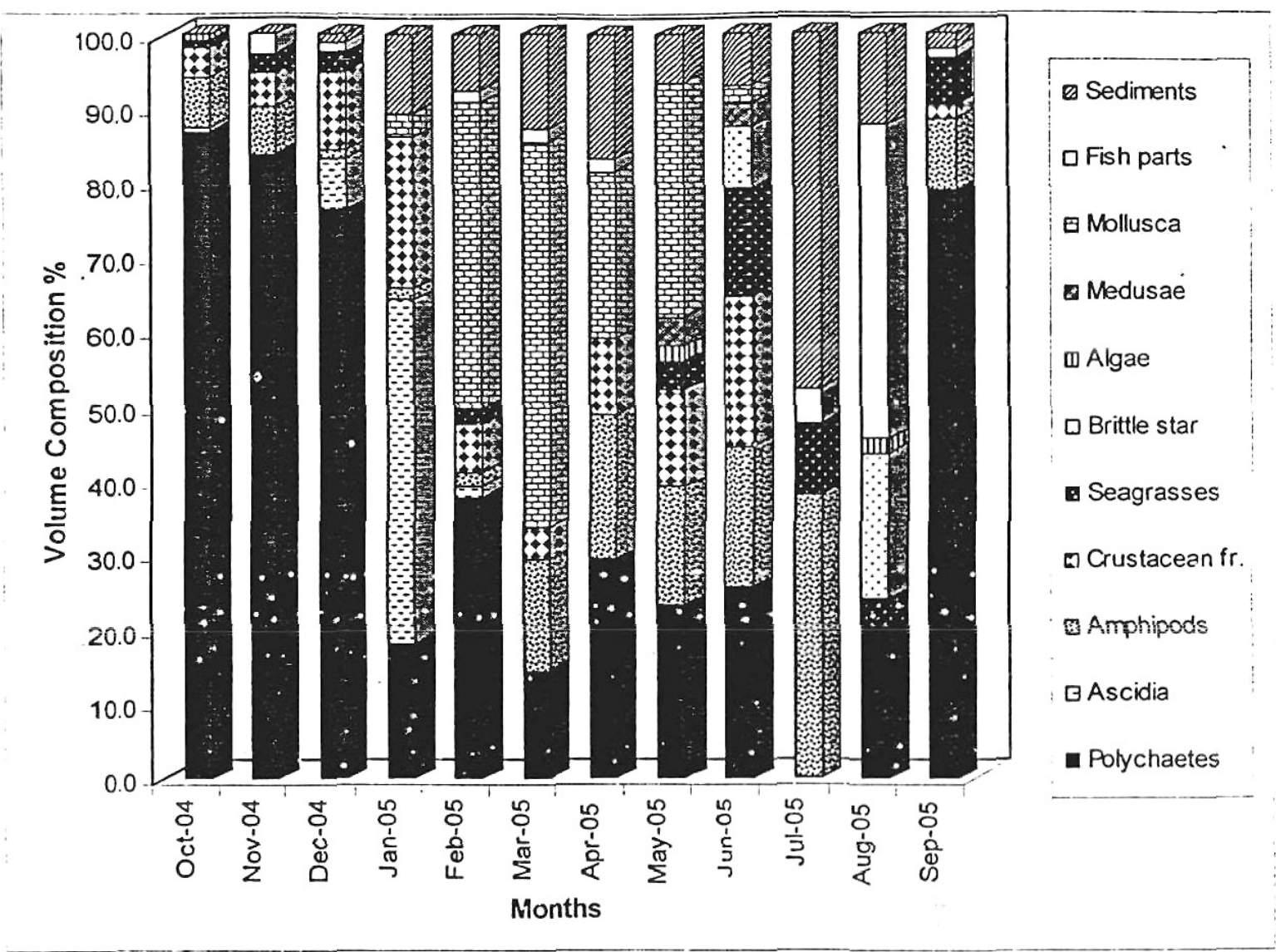

Figure (2): Monthly Variation in food items of Solea aegyptiaca. 


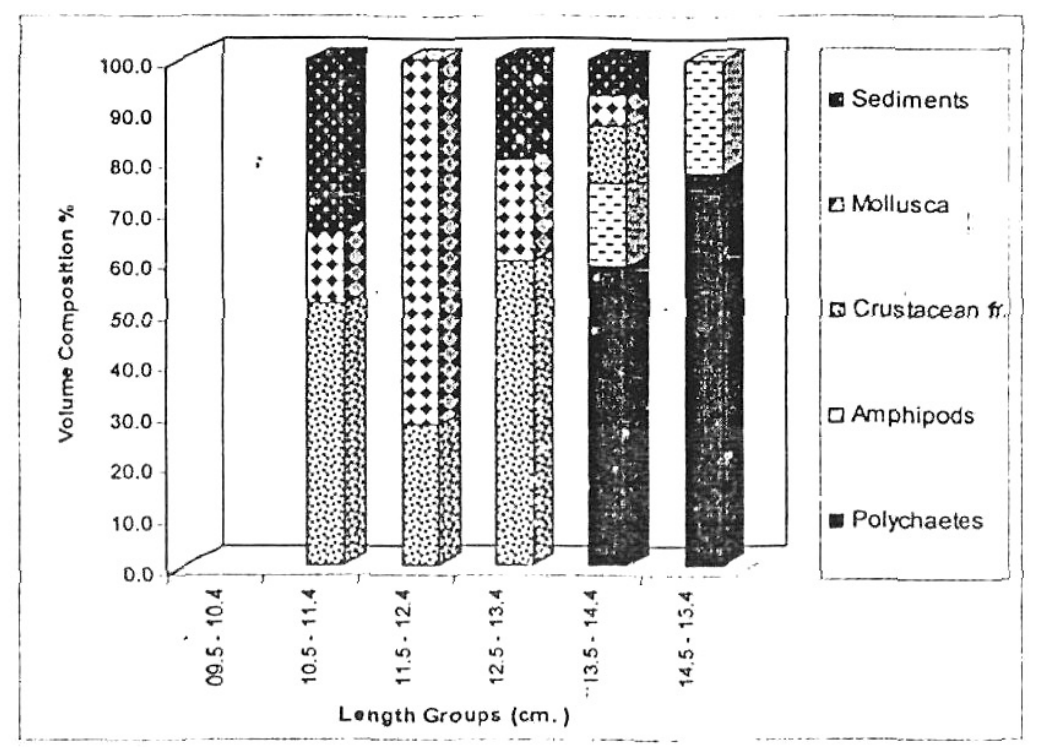

A) Juvenile

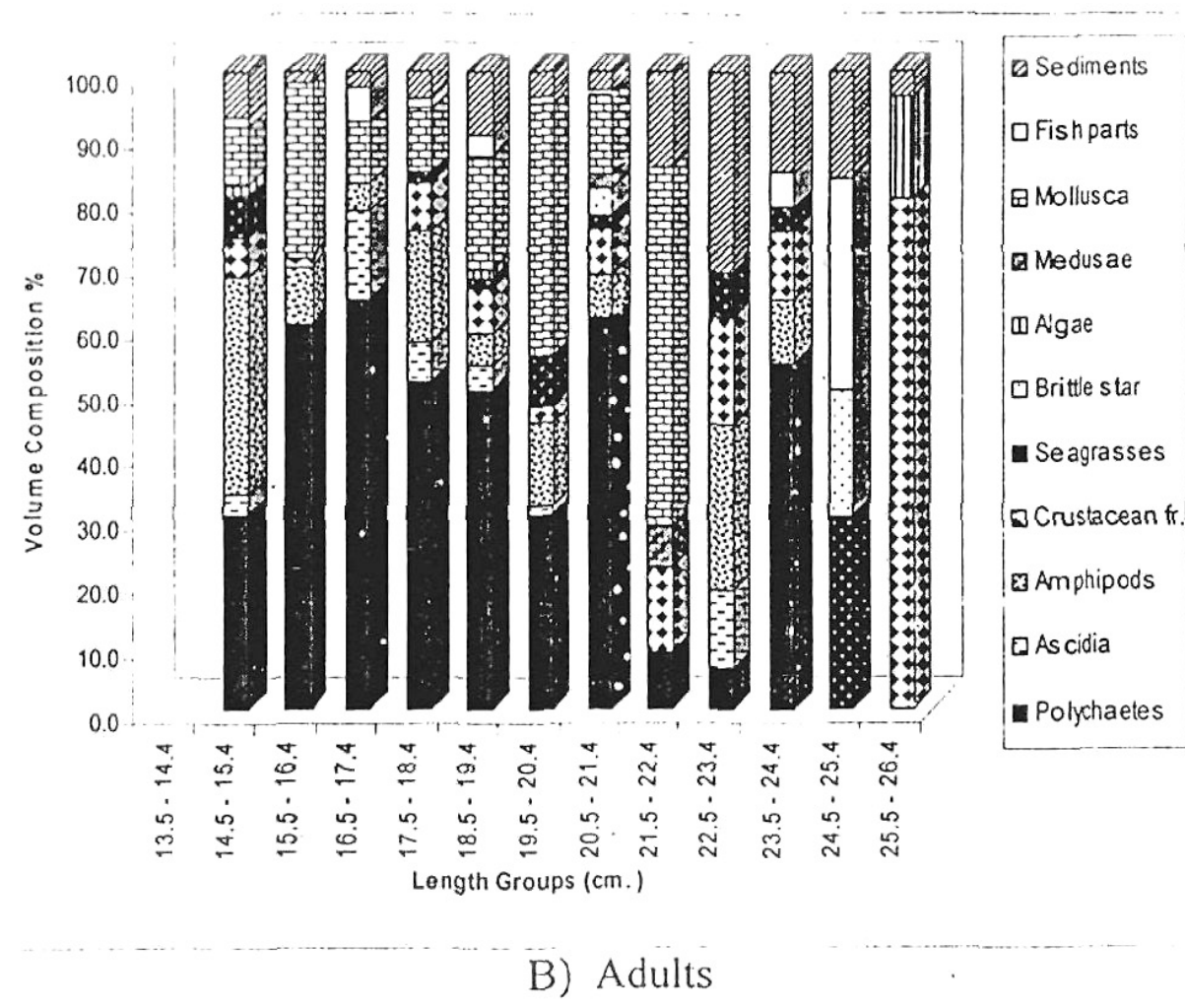

Figure (3): Diet Composition with different Size Classes of Solea aegyptiaca. 